\title{
RESEARCHPAPER
}

\section{Production and optimization of cellulase enzyme using cheap substrates by Aspergillus niger isolated from soil}

\author{
N.C. Tharavathy \\ Department of Studies and Research in Biosciences, Mangalore University, Mangalore (Karnataka) India
}

Article Info : Received : 20.12.2017; Revised : 05.03.2018; Accepted : 19.03.2018

\begin{abstract}
Studies were conducted on the production and optimization of cellulase enzyme using cheap substrates namely saw dust, sugarcane waste, coconut coir waste and newspaper waste by Aspergillus niger. A. niger was isolated from soil, cultured and sub-cultured in the laboratory to obtain pure culture. Cellulase production was done by solid state fermentation using four substrates separately. The isolate Aspergillus niger was studied for its growth kinetics, cellulose enzyme production, optimum $\mathrm{pH}$ and temperature, and time profile. Growth kinetics of Aspergillus niger showed that the stationary phase reached between day 4 and 6. A. niger reported growth and enzyme production in all the four substrates but among the four, coconut coir showed maximum cellulase enzyme activity $(3.0 \pm 0.10 \mathrm{U} / \mathrm{g})$ followed by sugarcane waste $(2.8 \pm 0.12 \mathrm{U} / \mathrm{g})$, newspaper waste $(2.4 \pm 0.15 \mathrm{U} / \mathrm{g})$ and saw dust $(2.0 \pm 0.12 \mathrm{U} / \mathrm{g})$. The optimal $\mathrm{pH}$ and temperature for the maximum biosynthesis of cellulase by $A$. niger were reported as $6.2 \pm 0.15$ and $28 \pm 0.5^{\circ} \mathrm{C}$, respectively. The production of cellulase was noticed after $96 \mathrm{~h}$ of incubation but maximum production of cellulose enzyme was reported in 120 hours.
\end{abstract}

Key words : Cellulase, Aspergillus niger, Saw dust, Sugarcane waste, Coconut coir waste, Newspaper waste

How to cite this paper : Tharavathy, N.C. (2018). Production and optimization of cellulase enzyme using cheap substrates by Aspergillus niger isolated from soil. Asian J. Bio. Sci., 13 (1) : 16-20.DOI : 10.15740/HAS/AJBS/13.1/16-20. 